\title{
Peran Apoteker Dalam Pharmaceutical Care; Konseling Terhadap Tingkat Pengetahuan Pasien TBC Rawat Inap Bagian Infection Center RSU dr Wahidin Sudirohusodo
}

\author{
Gemy Nastity Handayany*, Farida \\ Jurusan Farmasi Fakultas Kedokteran dan IImu Kesehatan UIN Alauddin Makassar \\ *Email korespondensi : gemynastity75@gmail.com
}

(Submit 15/03/2019, Revisi 05/09/2019, Diterima 20/12/2019)

\begin{abstract}
Abstrak
Pelayanan kefarmasian merupakan pelayanan yang tidak terpisahkan dari sistem pelayanan kesehatan dirumah sakit. Pelayanan farmasi inilah yang mendorong rumah sakit untuk senantiasa meningkatkan mutu pelayanan dalam rangka mencapai kepuasan pasien dalam hal pengetahuan tentang penyakit yang diderita termasuk penyakit TBC, hal ini juga disebut dengan pharmaceutical care. Berdasarkan fakta yang terjadi di lapangan terlihat bahwa masih banyak pasien yang kurang paham mengenai hal-hal yang terkait dengan penyakit TBC, baik dari segi pengobatan hingga proses penyembuhan. Hal ini diperkirakan terjadi karena pasien tidak mendapatkan Konseling yang baik oleh apoteker atau tidak pernah mendapatkan konseling sama sekali. Oleh karena itu peneliti ingin mengetahui pengaruh Pharmaceutical care terhadap tingkat pengetahuan pasien TBC serta tingkat kepatuhan pasien dalam pengobatan TBC. Berdasarkan hasil analisis uji paired sample t-test diperoleh nilai signifikasi sebesar 0.001 ( $p<0.05)$. Dari hasil tersebut dapat disimpulkan bahwa ada perbedaan tingkat pengetahuan setelah diberikan konseling. Sehingga dapat disimbulkan bahwa pengetahuan pasien sebelum diberikan pharmaceutical care dalam hal ini konseling lebih kecil atau rendah dibandingkan dengan setelah diberikannya pharmaceutical care terhadap pasien mengenai penyakit TBC.
\end{abstract}

Kata kunci: Pharmaceutical Care, Tuberculosis, Uji paired sample t-test

\section{Outline}

- Pendahuluan

- Metode

- Hasil dan Pembahasan

- Kesimpulan

- Saran

- Daftar Pustaka

\section{Pendahuluan}

Pelayanan kefarmasian merupakan pelayanan yang tidak terpisahkan dari sistem pelayanan kesehatan dirumah sakit. Dewasa ini pelayanan farmasi rumah sakit dituntut membangun paradigma sebagai pelayanan yang berorientasi kepada pasien sesuai mutu pelayanan farmasi. Keterlibatan berbagai pihak sangat diperlukan, baik dalam 
sektor masyarakat, kalangan swasta, organisasi profesi dan organisasi sosial serta LSM, terutama profesi apoteker diapotek, instalasi farmasi rumah sakit maupun tempat lain yang melayani masyarakat dalam memenuhi kebutuhannya akan ketersediaan obat khususnya obat golongan antituberkulosis.

Pada penelitian yang dilakukan oleh Riset Kesehatan dasar (Riskesdas) yang dilaksanakan oleh Badan Penelitian dan Pengembangan Kesehatan, Kementrian Kesehatan RI (2013), didapatkan angka prevalensi TB yang pada tahun 1990 hingga tahun 2013 disimpulkan mengalami peningkatan. Peningkatan jumlah penderita TB disebabkan oleh berbagai faktor, yakni kurangnya tingkat kepatuhan penderita untuk berobat dan meminum obat, dan lain sebagainya. Berdasarkan paparan diatas, maka peneliti tertarik membahas tentang pengaruh Pharmaceutical care terhadap tingkat pengetahuan pasien TBC serta tingkat kepatuhan pasien dalam pengobatan TBC.

\section{Metode}

Penelitian ini merupakan penelitian dalam bentuk survey yang bersifat observasional dengan metode pendekatan cross sectional, yaitu suatu penelitian yang dilakukan dengan pengamatan sesaat atau dalam suatu periode waktu tertentu dan setiap subyek studi hanya dilakukan satu kali pengamatan selama penelitian.

\section{A. Pendekatan Penelitian}

Penelitian ini menggunakan pendekatan kuantitatif untuk mendeskripsikan tingkat pengetahuan pasien setelah diberikan pharmaceutical care: konseling.

\section{B. Metode Pengumpulan Data}

Data penelitian diperoleh dari kuesioner yang telah diisi lengkap oleh responden yang dikumpulkan dengan teknik pengumpulan data secara consecutive sampling.

\section{Instrumen Penelitian}

Instrumen yang digunakan untuk mengukur variabel penelitian ini dengan menggunakan guttman. Skala Guttman yaitu skala yang menginginkan tipe jawaban tegas, seperti jawaban benar - salah.

Tabel 1. Skala Guttman

\begin{tabular}{|c|c|}
\hline Penilaian & Skor \\
\hline Benar & 1 \\
\hline Salah & 0 \\
\hline
\end{tabular}

\section{Analisis Data Penelitian}

1. Normalitas data. Uji normalitas data bertujuan untuk menguji apakah sebaran data terdistribusi normal atau tidak.

2. Uji $t$ test dependen (berpasangan). Uji $t$ test dependen digunakan untuk membandingkan rata-rata nilai pre-test dan nilai post-test pada satu sampel.

\section{Hasil dan Pembahasan}

Hasil didapatkan dari 16 responden mengalami peningkatan skor pengetahuan setelah 
diberikan konseling tentang penyakit TBC. Secara spesifik dijabarkan pada grafik perbandingan peroleh nilai pre test dan post test responden berikut ini.

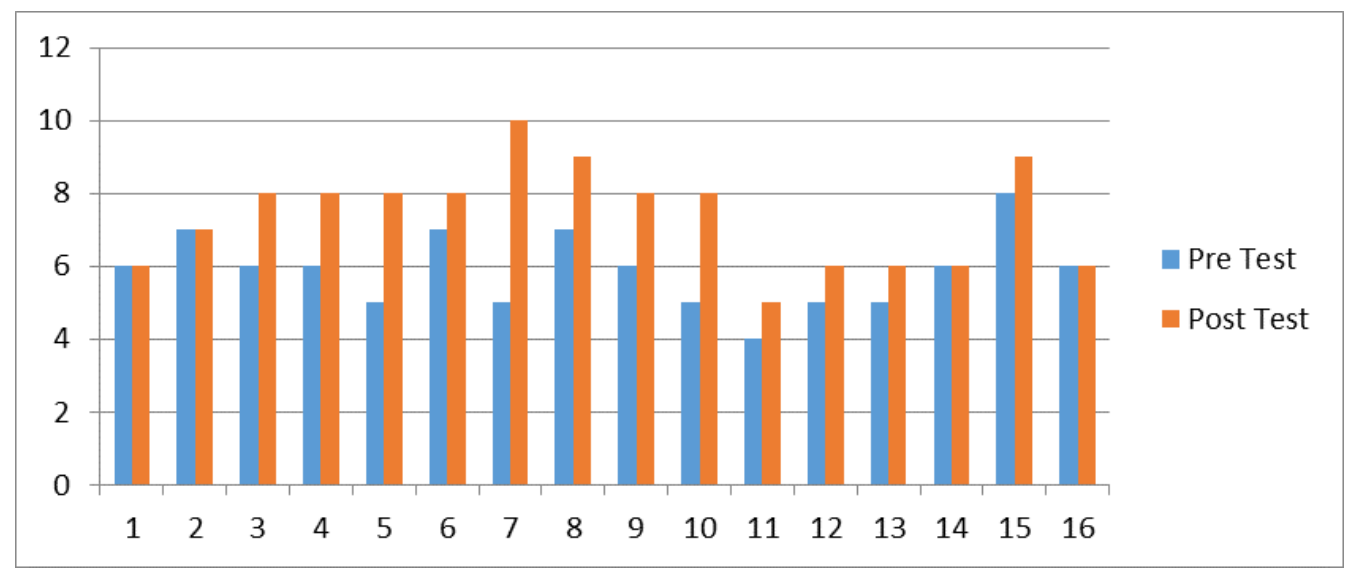

Gambar 1. Grafik pre dan post test

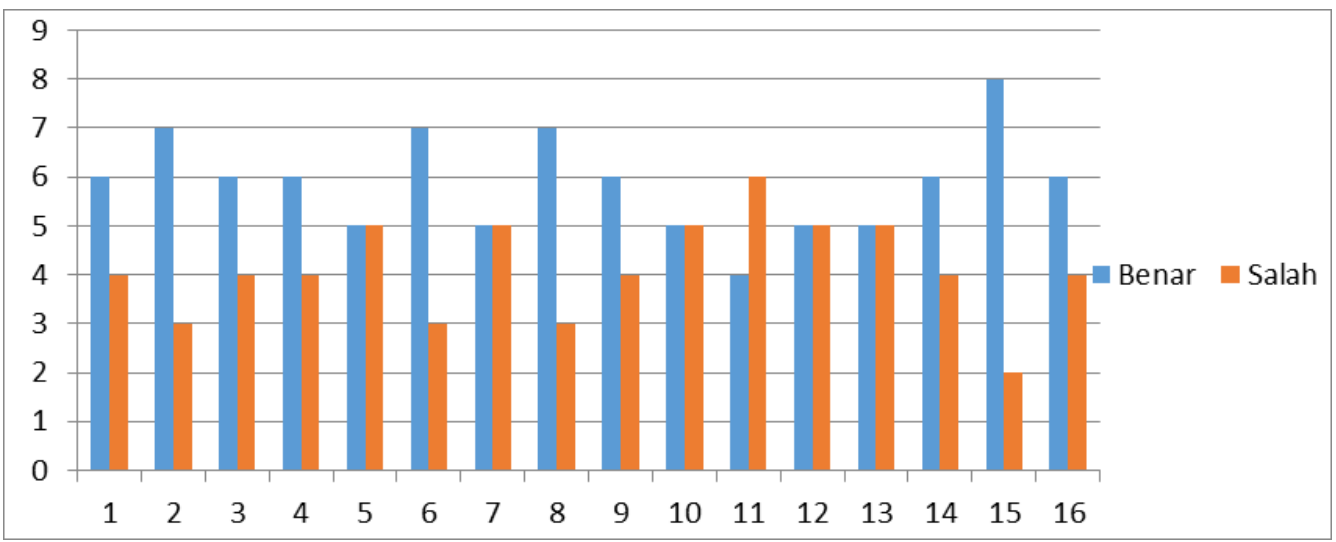

Gambar 2. Grafik pre test

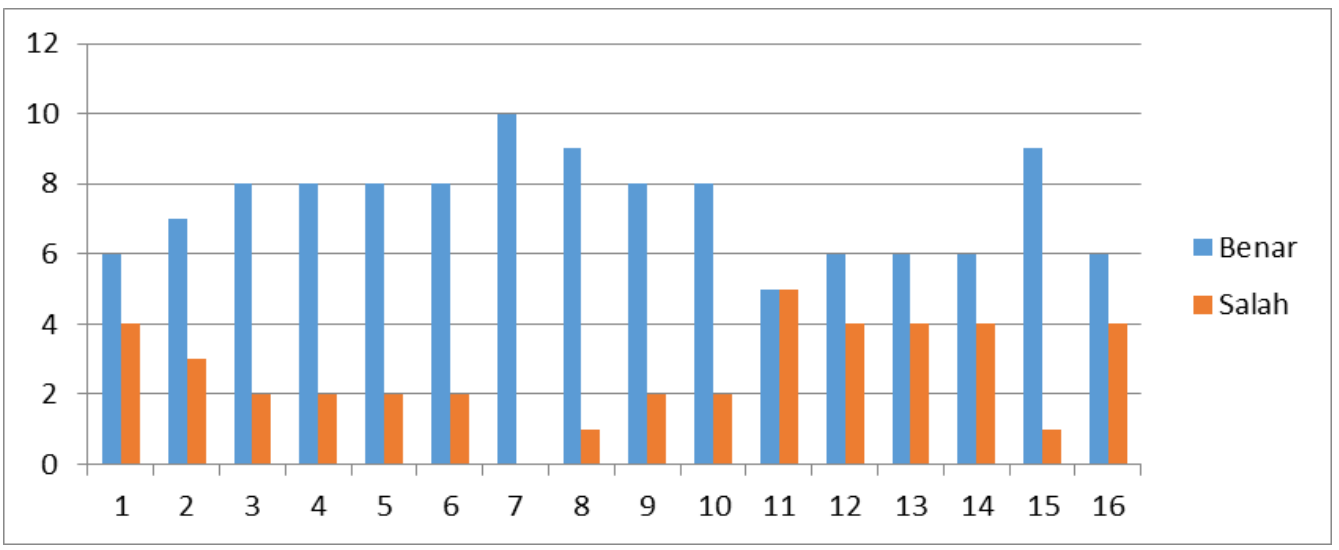

Gambar 3. Grafik post test

A. Analisis data tingkat pengetahuan pre dan post test

Tabel 2. Hasil Uji Paired Sample T-test

\begin{tabular}{|c|c|c|c|c|c|}
\hline Variabel & Rata-rata & N & P-value & T hitung & Ket. \\
\hline Pre-test & 5,88 & 16 & 0,001 & 4,932 & Signifikan \\
\hline Post-test & 7,38 & & & \\
\hline
\end{tabular}




\section{B. Pemilihan Uji Paired Test dalam Penelitian}

Uji paired test bertujuan membandingkan rata-rata dua variabel sebelum dan setelah diberikan stimultan atau penggerak perbedaan dalam penelitian dilakukan. Berdasarkan tabel 4.5 menunjukkan bahwa nilai rata-rata nilai sebelum diberikan konseling farmasi adalah sebesar 5,88 , sedangkan rata-rata nilai setelah diberikan konseling farmasi adalah 7,38 . Nilai $t$ hitung yang diperoleh dari uji paired sample t-test sebesar 4,392 dengan nilai $p$-value sebesar 0.001 . Hal ini menunjukkan nilai $p$-value lebih kecil dari nilai signifikansi yakni 0.05 . sehingga hipotesis dalam penelitian ini diterima. Hal ini dapat diartikan bahwa ada perbedaan tingkat pengetahuan pretest dan posttest.

\section{Pengetahuan Pasien Sebelum Diberikan Konseling (Pre-tets)}

Penelitian dilakukan dengan tujuan mengetahui apa yang terjadi sebelum dan setelah pasien dikonseling. Sebelum diberikan konseling terhadap pasien, dilakukan pengujian pre-test responden yang memenuhi kriteria inklusi. Hasil penelitian menunjukkan tingkat kemampuan menjawab dengan benar responden masih rendah. Hal ini disebabkan oleh masih kurangnya pengetahuan responden terhadap penyakit TBC sebagaimana yang telah dijadikan sebagai pernyataan pada kuisioner. Hasil pengujian yang dilakukan terhadap 16 responden menunjukkan bahwa kualitas jawaban berada pada rata-rata 5,88 berdasarkan hasil uji paired test. Tentu ini menunjukkan rata-rata yang rendah dari apa yang diharapkan. Derajat kebebasan penelitian ini jika dihitung dengan formula (nk-1) menghasilkan angka $13(16-2-1)$ dengan $t$ tabel 3,0129. Hasil T-Hitung menunjukkan angka 4,392 >3,0129. Ini membuktikan bahwa hipotesis ini diterima. Nilai p-value bernilai $0,01(<0,05)$ juga menunjukkan bahwa memang seharusnya konseling diberikan kepada pasien TBC untuk meningkatkan kualitas hidup mereka ke depannya.

\section{Pengetahuan Pasien Setelah Diberikan Konseling (Post-test)}

Berdasarkan penelitian yang telah dilakukan oleh peneliti di lapangan, pasien yang mengidap penyakit TBC yang diberikan konseling farmasi memang seharusnya memiliki perbedaan tingkat pengetahuan yang signifikan, hal ini dapat dipengaruhi oleh pengendalian oleh pasien itu sendiri. oleh karenanya, pasien sebelum diberikan konseling akan memiliki pengetahuan yang sedikit terhadap pengobatan penyakit TBC sedangkan pasien yang telah diberikan konseling akan memiliki pengetahuan yang lebih besar terhadap pengobatan penyakit TBC (Lihat Tabel 2). Sehingga konseling ini sangat perlu diberikan kepada pasien untuk meningkatkan pengetahuan responden terhadap TBC itu sendiri.

\section{E. Tingkat perbandingan pengetahuan pasien pre dan post test setelah diberikan konseling}

Berdasarkan hasil uji paired sample t-test diperoleh nilai signifikasi sebesar $0.001(p<$ 0.05 ) yang menunjukkan signifikansi perubahan yang sangat positif. Dari hasil tersebut dapat disimpulkan bahwa ada perbedaan tingkat pengetahuan setelah diberikan konseling. Sehingga dapat disimbulkan bahwa pengetahuan pasien sebelum diberikan pharmaceutical care dalam hal ini konseling lebih kecil atau rendah dibandingkan dengan setelah diberikannya pharmaceutical care terhadap pasien mengenai penyakit TBC. Hal ini menunjukkan bahwa pharmaceutical care sangat berperan penting dalam peningkatan pengetahuan pasien terhadap penyakit TBC. 


\section{Kesimpulan}

Dari hasil penelitian Pharmaceutical Care di RSU Dr. Wahidin Sudirohusodo membuat kesimpulan bahwa ada perbedaan tingkat pengetahuan antara pasien sebelum diberikan konseling farmasi dan setelah diberikan konseling farmasi. Hal ini dapat dilihat dari nilai $p$-value yang lebih kecil dari nilai signifikansi yaitu $0.001(p<0.05)$ yang berarti Pharmaceutical Care berpengaruh signifikan terhadap tingkat pengetahuan pasien terhadap pengobatan TBC.

\section{Saran}

Adapun saran yang diberikan penulis adalah sebagai berikut :

1) Untuk menjaga kualitas pelayanan Pharmaceutical Care sebaiknya apoteker yang berkualifikasi diperbanyak.

2) Untuk peneliti selanjutnya dapat menggunakan metode yang lain untuk mengetahui pengaruh Pharmaceutical Care terhadap kesembuhan penyakit TBC.

\section{Daftar Pustaka}

1. Alfid, Afandi,Tri. Efektifitas peer group support terhadap kualitas hidup klien TB paru dan penyakit kronik. Program ilmu keperawatan, Jember. 2016

2. Amiluddin,Zumla, dkk. Tuberculosis, New England. 2013

3. Antimicrob. Chemother. 2011. Hal 180.

4. Asih, yasmin, gede, niluh, Christiantie, effendi, Klien dengan gangguan sistem pernafasan, Jakarta. 2004

5. Depkes RI. Pedoman penaggulangan nasional TBC. Jakarta.2008. Hal 1,25.

6. Depkes RI. Standar pelayanan kefarmasian di rumah sakit, Jakarta. 2016. Hal 3

7. Depkes RI.Pharmaceutical care untuk penyakit tuberkulosis. 2005 . Hal 25.

8. Devi, Darliana. Manajemen pasien tuberkulosis paru. Syiah kuala university. 2017. Hal 83.

9. Dileep,Tiwari,dkk. Vaccine development for tuberkulosis past, present and future challenges, The netherlands. 2011. 75.

10. Eka, Fitriani. Faktor resiko yang berhubungan dengan kejadian tuberkulosis paru, Semarang.2013. Hal 90.

11. Enti, Rikomah, Setya,. Farmasi klinik, Yogyakarta.2016. Hal 58, 45

12. Farandika, Reiza, Kurniawan. Rahasia terbaru kedahsyatan terapi enzim,

13. Fortun, J. Linezolid for the treatment of multidrug-resistant tuberculosis. J.

14. Hair, J.F, et. al. Multivariate Data Analysis with Reading 4rd Edition. New Jersey: Prentice Hall Internationa. 2010. Hal. 92.

15. Handayani Gemy Nastity. Disertasi pengaruh mutu pelayanan kefarmasian dan kompetensi petugas terhadap ketersedian obat, serta dampaknya pada kepuasan pasien dirumah sakit umum daerah (RSUD) labuang baji provensi sulawesi selatan.,Surabaya.2017. Hal 7.

16. Handayany, Gemy,Nastity. Pengaruh mutu pelayanan kefarmasian dan kompetensi petugas terhadap ketersediaan obat serta dampaknya kepada kepuasan pasien di rumah sakit umum daerah (RSUD) labuang baji provinsi sulawesi selatan. Surabaya.2017.Hal. 7. 
17. Hepler, stard. Opportunities and responsibilities in pharmaceutical care, American journal of hospital pharmacy.1990

18. Husein, Surahman, E. Konsep dasar pelayanan kefarmasian berbasiskan pharmaceutical care. Widya Padjadjaran, Bandung.2011

19. Icksan, Aziza, G, dan Reny, Luhur, S. Radiologi toraks Tuberkulosis paru, Jakarta. 2001. Hal 4.

20. Idris Fachmi. Panduan praktis edukasi kesehatan, Jakarta.2014. Hal 4.

21. Irman, Somatri. Asuhan keperawatan pada pasien dengan gangguan sistem pernafasan, Jakarta.2007. Hal 15.

22. ISFI. informasi spesialis obat indonesia, , Jakarta.2000. Hal 23.

23. Jakarta : JRI. 2000. Hal 42.

24. Jakarta; Kementerian Kesehatan RI. 2011.Hal 6.

25. Jasaputra, Diana, K,Slamet, Santosa. Metodologi penelitian biomedis. Bandung. 2008. Hal 47.

26. John, Bernardo dan Rocarati. Tuberculisis (TB),AS.2012

27. Kemenkes RI. Undang-Undang Republik Indonesia Nomor : 23 tahun 2005 Tentang Kesehatan, Jakarta. 2005. Hal 15-40.

28. Kemenkes RI. Profil Kesehatan Indonesia Tahun 2009, Jakarta. 2010. Hal 4.

29. Kemenkes RI. Promosi kesehatan di daerah bermasalah kesehatan panduan bagi petugas kesehatan di puskesmas, Jakarta: Pusat Promosi Kesehatan Kemenkes Republik Indonesia. Available at: http://www.depkes.go.id/resources/download/promosi-kesehatan/panduanpromkes-dbk.pdf. 2011. Hal 190.

30. Kemenkes RI. Standar pelayanan kefarmasian di apotik, Jakarta. 2004. Hal 3,8.

31. Kemenkes RI. Strategi Nasional Pengendalian TB di Indonesia 2010-2014.

32. Kemenkes RI. Strategi Nasional Pengendalian TB di Indonesia. Jakarta. 2014

33. Kusuma Dharma Kelana. Metode penelitian keperawatan, Jakarta. 2011. Hal 78.

34. Mappiare, Andi. pengantar konseling dan psikoterapi, Jakarta.2010. Hal 5.

35. Masrin. Tuberkulosis Paru. Jurnal Universitas Muhamadiyah Semarang.2008. Hal 5 .

36. Nadesul, handrawan. Dari balik kamar prakter dokter tips praktis mengenali, mencegah dan mengatasi penyakit. Jakarta.2009

37. Nazir, Moh. Metode Penelitian. Bogor: Ghalia Indonesia. 2005

38. Niluh, Yasmin, Gede. Buku Kedokteran, Jakarta. 2004. Hal 83.

39. Nurhikmah, Siti. Hubungan antara karakteristik individu dan lingkungan dengan kejadian tuberkulosis di puskesmas bojongsari purbalingga, Purwekerto. 2016. Hal 19

40. Nurlita,Niviasari. Faktor faktor yang berhubungan dengan status kesembuhan penderita tuberkulosis paru, semarang. 2015. Hal 143.

41. Nursalam. Konsep dan penerapan metodologi penelitian ilmu keperawatan. Jakarta. 2008. Hal 34.

42. PDPI. Pedoman diagnosis dan penatalaksanaan tuberkulosis di indonesia, Jakarta. 2006. Hal 28-29.

43. Peraturan Daerah. Tarif layanan kesehatan pada badan layanan umum daerah rumah sakit umum daerah kota makassar.2016. Hal 4.

44. Permenkes RI. Standar pelayanan kefarmasian rumah sakit. Jakarta. 2016. Hal 25. 
45. Prayitno. Jenis Layanan dan Kegiatan Pendukung Konseling. Padang: Fakultas Ilmu Pendidikan UNP. 2012. Hal 101.

46. Rancarati, Bernardo,John. Tuberculosis (TB). 2012

47. Rovert, J. P., et al. A Practical Guide to Pharmaceutical Care, American Pharmaceutical Association, Washington, D.C. 2003. Hal 93.

48. Shihab, M. Quraish. Tafsir Al - Mishbah. Jakarta: Lentera Hati. 2002. Hal 453,587.

49. Shubashini, Gnanasan. Pharmaceutical care for patiens tuberculosis and diabetes mellitus in malaysia, 2012

50. Singarimbun dan Effendi. Metode Penelitian Survay. Jakarta: PT Pustaka LP3ES Indonesia. 2011. Hal 124, 142,144.

51. Siswanto,dkk. Metodologi penelitian kesehatan dan kedokteran. Yogyakarta. 2015: Hal 15,217,310.

52. Soedarto. Penyakit- penyakit infeksi di indonesia. Surabaya.1996. Hal 52.

53. Sudjana. Metode dan teknik pembelajaran partisipatif, Bandung. 2001. Hal. 15.

54. Sugiono. Metodologi penelitian kuantitatif dan kualitatif dan R\&D, Bandung. 2008. Hal 142.

55. Sukandar. ISO Farmakoterapi, ISFI Penerbitan, Jakarta. 2007. Hal 918.

56. Suryanto, E. Tuberkulosis dan HIV. Dalam Jurnal Respirologi Indonesia.

57. Suyono,. Buku ajar penyakit dalam II FKUI, Jakarta. 2001. Hal 31.

58. Syarifuddin, M. 2013. Peranan Pharmaceutical Care dalam Meningkatkan Hasil Klinis dan Kualitas Hidup Pasien Penderita Diabetes Melitus. Jurnal Kefarmasian Indonesia, 3(2): 52-59.

59. Wibowo. Manajemen kinerja, Jakarta. 2012. Hal 52.

60. Word Health Organization (WHO). Global Tuberkulosis Report 2015. Switzerland. 2015

61. World Health Organization (WHO). About Cardiovascular diseases. Geneva. 2013. Hal 1,3. 